\title{
Increasing forage yield and effective weed control of corn-soybean mixed forage for livestock through using by different herbicides
}

\author{
Yowook Song ${ }^{1}$, Muhammad Fiaz ${ }^{2}$, Dong Woo Kim¹, Jeongtae Kim¹ and Chan Ho Kwon ${ }^{1 *}$ \\ ${ }^{1}$ Department of Animal Science and Biotechnology, Kyungpook National University, Sangju 37224, Korea \\ ${ }^{2}$ Department of Livestock Management, Cholistan University of Veterinary and Animal Sciences Bahawlpur, Punjab, Pakistan
}

\begin{abstract}
The aim of this study was to evaluate different herbicides for optimum growth, yield and nutritive value of corn-soybean mixed forage under randomized complete block design. The experimental site was selected and divided equally into 3 blocks. Each block was further divided into 5 plots that each plot had 15 square meter space $(3 \times 5)$. Five herbicidal treatments were randomly applied over 5 plots and herbicides were used under 5 herbicidal treatments, viz. 1) No herbicide (control); 2) Pendimethalin; 3) Linuron; 4) S-metolachlor and 5) Ethalfluralin. The collected data were analyzed using ANOVA through SAS 9.1.3 software. The results indicated that growth characteristics were not influenced $(p>0.05)$ by any herbicide. However, arithmetically corn stalk height was highest in the field of Pendimethalin treatment, whereas highest soybean height was found in the field of S-metolachlor. Arithmetically dry matter (DM) yield was increased with herbicidal treatments as compared to that of control treatment. Relatively highest DM yield (130\%) was recorded in the treatment of Ethalfluralin followed by Pendimethalin (126\%), S-metolachlor (126\%) and Linuron (108\%) as compared to that of control treatment. The weed emergence was significantly reduced in all herbicidal treatments as compared to that of control $(p>0.05)$, but the difference among herbicidal treatments was non-significant. It was concluded that weed emergence can be effectively controlled by use of any tested herbicide. However, optimum DM yield can be achieved through using herbicides; Ethalfluralin, Pendimethalin and S-metolachlor.
\end{abstract}

Keywords: Corn, Soybean, Intercropping, Herbicides, Productivity

\section{Background}

The consumption trend of animal origin food has been increasing in Korea for last few years. It has become a good driving force to increase the production status of livestock products in the country as depicted by Korean livestock statistics. The livestock statistic's comparison of years 2018 and 2014 showed adequate increase in number of different livestock species; beef cattle $+5 \%(3,104$ to 3,117 ), dairy cattle-1.0\% (442 to 407$)$, pig $+1.3 \%$ (9,966 to
$11,641)$, layer $+5 \%(65,263$ to 71,227$)$ and broiler $+3.4 \%(75,846$ to 83,278 ) thousands [1].

Feeding resources and specifically forage is the prime requirement of rearing variety of livestock species. The researchers and academicians are embarked to enhance the self-sufficiency of forage production under limited land resources in country through innovative forage production techniques. Corn and soybean intercropping or mixed cropping is well suited innovative forage production technique under South Korean conditions [2]. However, native 
farmers face unwanted allied weeds with their crop plants and bear considerable losses in terms of forage productivity because weeds always compete crop plants for nutrients to grow parallel. Hence, weeds have been authenticated serious issue which may cause forage productivity losses [3]. The range $40 \%$ to $60 \%$ of production losses in corn has been already documented due to weed infestation [4]. Manual weed removal at optimal time is best possible solution to reduce forage productivity but rarely adopted as it is tedious and time-consuming job.

As rapid industrialization and urbanization, enormous young labor force have been shifted to urban area for better employment opportunities. Consequently, the labor gets limitedly available for weeding and other farm operations. Therefore, use of herbicides for weed removal gets popularized to reduce eventual forage production losses and have been promising weed control method [5-8]. However, haphazard usage of herbicide may cause adverse effects because some herbicides are well suited for corn but not for soybean in intercropping field [9]. Therefore, present study plan was designed with objective to evaluate different herbicides and findout most suitable herbicide for optimum growth, yield and nutritive value of corn-soybean mixed forage to be fed as basal diet for livestock.

\section{Materials and Methods}

\section{Location of study}

The experiment was carried out at research farm located in Cheongri, Sangju-si, Gyeongsangbuk-do, Korea from $23^{\text {rd }}$ May to $1^{\text {st }}$ September, 2016. Geographical coordinates of research site were $36.3323^{\circ} \mathrm{N}, 128.1287^{\circ} \mathrm{E}$.

\section{Climate of research site}

Climate in terms of temperature and rainfall of research site recorded during trial with 10 years history is given in Table 1.

\section{Experimental treatments}

The chemical properties of the experimental site is given in Table 2. The experiment was conducted under randomized complete block design (RCBD) and the design of experimental was shown in Fig. 1. An area of land (length $17 \mathrm{~m}$ and width $15 \mathrm{~m}$ ) is selected and divided equally into 3 blocks; Block A, Block B, and Block C.
Table 1. Comparative average temperature and total rainfall in field area of Sangju-si, Gyeongsangbuk-do, Korea

\begin{tabular}{lccccc}
\hline Climate & Year & May & June & July & August \\
\hline Temp $\left({ }^{\circ} \mathrm{C}\right)$ & 2016 & 19.8 & 23.7 & 25.9 & 27.1 \\
& $2006-$ & 18.41 & 22.4 & 24.7 & 25.1 \\
& 2015 & & & & \\
\hline $\begin{array}{l}\text { Rainfall } \\
(\mathrm{mm})\end{array}$ & 2016 & 52.8 & 47 & 313.6 & 116.3 \\
& $2006-$ & 91 & 112.2 & 255.4 & 230.3 \\
\hline
\end{tabular}

Korea Meteorological Administration, 2016 [10].

Each block was further divided into 5 plots so that each plot had 15 square meter space $(3 \times 5)$. Five herbicidal treatments were randomly applied over 5 plots in each block. The blocks were defined as 3 replicates. Different herbicides were used under 5 herbicidal treatments, viz. 1) No herbicide (control); 2) Pendimethalin; 3) Linuron; 4) $S$-metolachlor and 5) Ethalfluralin.

\section{Land preparation}

The soil of experimental land was sandy in nature having chemical properties given in Table 2. The chemical fertilizer N-P-K (21:17:17) was applied at the rate $1,000 \mathrm{~kg}$ per hectare before seeding for experiment.

\section{Seeds and seeding}

The variety of corn seed used was Pioneer-32P75, whereas variety of soybean seed was Chookdu- 1 which selected from a cross between PI483463 and Hutcheson were used for experiment. Seeding of corn and soybean was carried out on 2 equally spaced rows in each plot as per experimental treatments. The space between corn and soybean rows was 0.75 meter. The seed to seed distance within a row from soybean to soybean was $10 \mathrm{~cm}$ and from corn to corn was $20 \mathrm{~cm}$ as fixed by seeding machine named Hwangeum (HG10A model). Two border rows around experimental area were examined to check the border effect.

\section{Parameters studied}

The effect of different herbicides on growth characteristics and productivity of corn-soybean intercropping forage was studied in terms of following parameters.

1. Height of corn stalk \& ear and soybean plant $(\mathrm{cm})$

2. Corn-soybean coupling (No.)

Table 2. Chemical properties of the experimental field soil

\begin{tabular}{|c|c|c|c|c|c|c|c|c|}
\hline \multirow{2}{*}{$\begin{array}{c}\mathrm{pH} \\
(1: 5)\end{array}$} & \multirow{2}{*}{$\begin{array}{l}E C \\
\text { (ds/m) }\end{array}$} & \multirow{2}{*}{$\begin{array}{c}\text { Available } \\
\text { phosphate } \\
\text { (mg/kg) }\end{array}$} & \multirow{2}{*}{$\begin{array}{c}\text { Organic } \\
\text { matter (g/kg) }\end{array}$} & \multirow{2}{*}{$\mathrm{N}(\%)$} & \multicolumn{4}{|c|}{ Exchangeable cations $\left(\mathrm{cmol}_{\mathrm{c}} / \mathrm{kg}\right)$} \\
\hline & & & & & $\mathrm{Ca}$ & $\mathbf{K}$ & Mg & $\mathrm{Na}$ \\
\hline 6.22 & 0.25 & 214.34 & 10.64 & 0.2 & 7.44 & 0.85 & 1.81 & 0.84 \\
\hline
\end{tabular}

$\mathrm{EC}$, electrical conductivity; $\mathrm{N}$, nitrogen; $\mathrm{Ca}$, calcium; $\mathrm{K}$, kalium; $\mathrm{Mg}$, magnesium; $\mathrm{Na}$, natrium. 


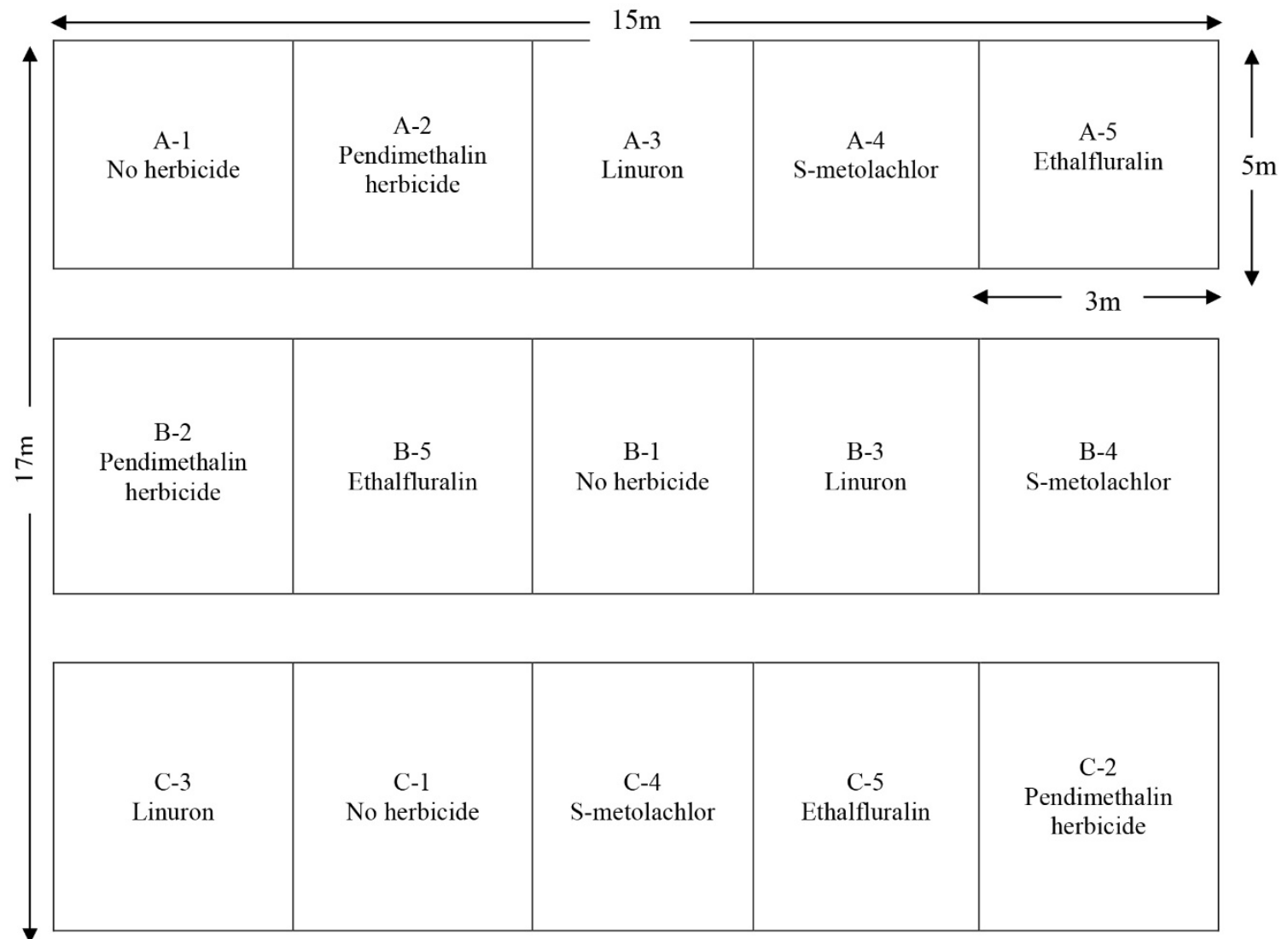

Fig. 1. Experimental design in Sangju-si, 2016.

3. Dry matter (DM) yield of corn, soybean \& total (tons/ha) 4. Neutral detergent fiber (NDF), acid detergent fiber (ADF), relative feed value (RFV) and total digestible nutrients (TDN) (\%) 5. Yield of TDN in corn, soybean \& total (tons $/ \mathrm{ha}$ )

6. Emergence of following weeds $\left(\mathrm{No} . / \mathrm{m}^{2}\right)$

- Chenopodium album

- Digitaria sanguinalis

- Portula caoleracea

- Echinochloa crus-galli

\section{Data collection}

Number of survived plants was counted 2 weeks post seeding on $21^{\text {st }}$ June, 2016. The counting of following weeds was also executed on $28^{\text {th }}$ June, 2016 for weed emergence, viz. 1) Chenopodium album, 2) Digitaria sanguinalis, 3) Portula caoleracea and 4) Echinochloa crus-galli. After counting of weed emergence, we left them to investigate how the growth of weeds affects the corn and soybean growths. Height of corn stalk, corn ear \& soybean was recorded on the day of harvesting, $1^{\text {st }}$ September 2016. The corn stalk height was measured from ground to the top of plant stamen, whereas height of corn ear was taken from ground to the stigma of ear evolved. Similarly, soybean height was measured from ground to the top of plant. Five average plants were taken from each replicate for measuring data regarding height. Number of stalk, ear \& soybean as well as corn-soybean coupling was recorded through counting on harvesting date.

\section{Laboratory analysis}

Samples of corn stalk, ear and soybean from each replicate were randomly taken for DM yield, initially weighed, dried in oven at $70^{\circ} \mathrm{C}$ for 72 hours $\&$ then again weighed after drying. The kilogram of DM yield was also converted into tons per hectare. The percentage of DM was just calculated using fresh yield and DM yield information. Fiber analysis (NDF \& ADF) were performed as per procedure of Van-Soest et al. in the laboratory of "Forage Production and Utilization”, Department of Animal Sciences and Biotechnology, Kyungpook National University Sangju Campus, Korea. The RFV and TDN were calculated through following equations [11,12],

$\mathrm{RFV}=$ Relative Feed Value $=(\mathrm{DDM} \times \mathrm{DMI}) / 1.29$

$\mathrm{DDM}=$ Digestible Dry Matter $=88.9-(0.779 \times \% \mathrm{ADF})$ 


\section{JAST}

DMI $=$ Dry Matter Intake $(\%$ of BW $)=120 /(\% N D F)$

$\% \mathrm{TDN}=$ Total Digestible Nutrients $=4.898+(89.796 \times \mathrm{NEL})$

NEL $($ Mcal $/$ lb $)=$ Net energy for lactation

$$
=1.0876-(0.0127 \times \mathrm{ADF})
$$

\section{Statistical analysis}

The collected data were analyzed using ANOVA technique through SAS 9.1.3 software. The difference among five treatment means was tested through Duncan Multiple Range Test [13].

\section{Results}

\section{Growth characteristics}

Effect of intercropping corn with soybean under different herbicides was determined in terms of following parameters. Fig. 2 shows the growth pattern under different herbicide of each experimental site. Results in Table 3 depicted that all growth characteristics were not influenced $(p>0.05)$ by any treatment. However, arithmetically corn stalk height was highest in the field of Pendimethalin treatment, whereas highest soybean height was found in the field of $S$-metolachlor. In case of corn-bean coupling number, it was decreased $(p>0.05)$ in the field of control treatment, however, the difference among other treatments was not significant $(p>$ 0.05).

\section{Dry matter yield}

The overall results in Table 4 indicated that no doubt DM yield was not different $(p>0.05)$ statistically among different treatment groups. However, arithmetically DM yield was increased with herbicidal treatments as compared to that of control treatment. Findings regarding total DM yield and relative DM yield depicted that relatively highest DM yield (130\%) was found in the treatment of
Ethalfuralin followed by Pendimethalin (126\%) and S-metolachlor (126\%). Whereas relative DM yield in case of Linuron was also better (108\%) than that of control treatment with herbicide use. Similarly, the soybean proportion was not significantly different, but control treatment was arithmetically lowest, whereas the impact of Ethalfluralin is the highest in among different treatment groups. The results shown that Ethalfluralin had less damage on soybean and ultimately produced higher level of soybean.

\section{NDF, ADF, RFV and TDN}

The effect of different herbicidal treatment on NDF, ADF, RFV and TDN was presented in Table 5. The statistical analysis showed that there was no difference $(p>0.05)$ among different herbicidal treatments. However, arithmetic difference was observed. The NDF in corn stalk was found lowest in Pendimethalin, whereas it was highest in control treatment. Similarly, ADF trend was lower in Pendimenthalin and Lunuron but Ethalfuralin and S-metolchlor were in higher levels on both corn stalk and soybean. In case of RFV and TDN values, highest trend was also found in Pendimethalin treatment except TDN\% in soybean.

\section{Emergence of following weeds}

The influence of different herbicidal treatments on emergence of various weeds is mentioned in Table 6. The emergence of Chenopodium album was found absent in case of Pendimethalin and Linuron herbicides. However, the difference among various treatments was non-significant $(p>0.05)$. In case of weed named Digitaria sanguinalis, its emergence was found lower $(p<0.05)$ in Pendimethalin, $S$-metolachlor and Ethalfluralin as compared to that of control treatment. However, emergence in case of Linuron was not different $(p>0.05)$ with all other treatments. The emergence of other weed named, "Portulaca oleracea" was also found absent in case of

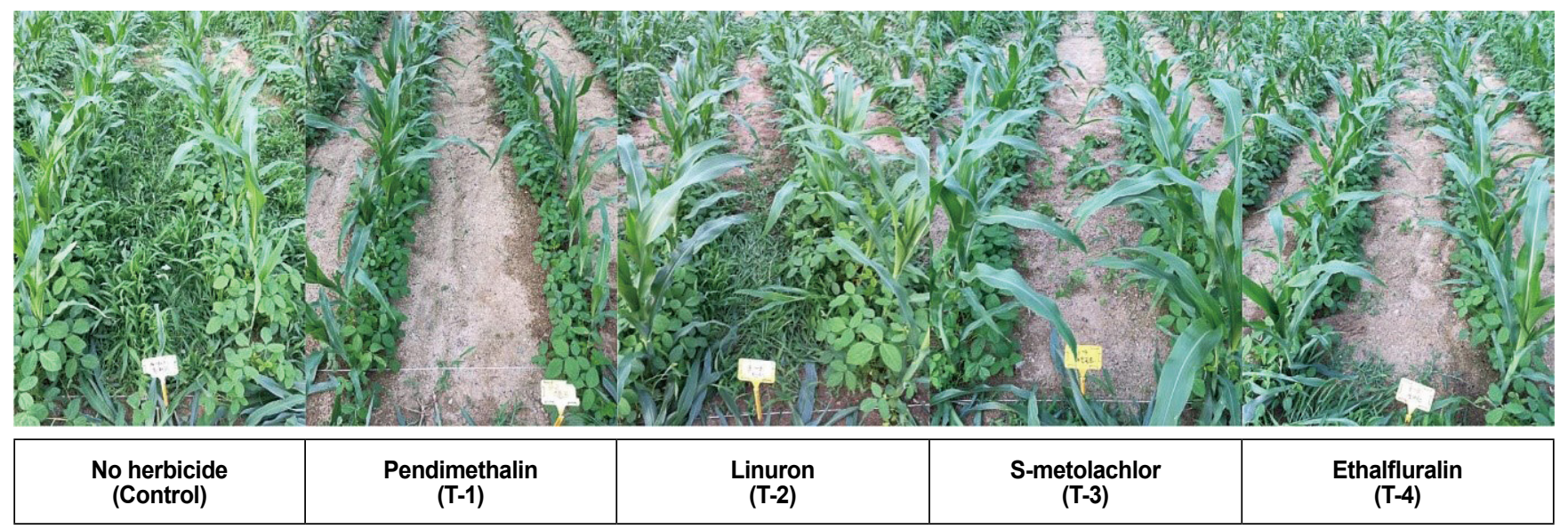

Fig. 2. Experimental sites and growth characteristics about each treatment in Sangju-si, 2016. 
Table 3. Effect of different herbicides on growth characteristics of plants in corn-soybean mixed cropping forage (Mean)

\begin{tabular}{|c|c|c|c|c|c|c|c|}
\hline \multirow{2}{*}{ Growth parameters } & \multicolumn{5}{|c|}{ Treatments } & \multirow{2}{*}{ SEM } & \multirow{2}{*}{$p$-value } \\
\hline & No herbicide & Pendimethalin & Linuron & S-metolachlor & Ethalfluralin & & \\
\hline Corn stalk height $(\mathrm{cm})$ & 299 & 312 & 300 & 297 & 306 & 10.6 & 0.940 \\
\hline Corn ear height $(\mathrm{cm})$ & 139 & 139 & 141 & 138 & 138 & 5.5 & 0.998 \\
\hline Soybean height $(\mathrm{cm})$ & 102 & 107 & 102 & 124 & 112 & 13.2 & 0.872 \\
\hline Corn-bean coupling (No. $/ 7.5 \mathrm{~m}^{2}$ ) & $13^{\mathrm{b}}$ & $36^{\mathrm{a}}$ & $31^{\mathrm{a}}$ & $35^{\mathrm{a}}$ & $39^{a}$ & 3.6 & 0.018 \\
\hline
\end{tabular}

a,b Variables having different superscripts in the same rows are significantly different $(p<0.05)$.

SEM, standard error of the mean.

Table 4. Effect of different herbicides on dry matter yield in corn \& soybean mixed cropping

\begin{tabular}{|c|c|c|c|c|c|c|c|}
\hline \multirow{2}{*}{ Dry matter yield } & \multicolumn{5}{|c|}{ Treatments } & \multirow{2}{*}{ SEM } & \multirow{2}{*}{$p$-value } \\
\hline & No herbicide & Pendimethalin & Linuron & S-metolachlor & Ethalfluralin & & \\
\hline Corn stalk (ton/ha) & 5.1 & 6.1 & 5.5 & 6.1 & 6.1 & 0.313 & 0.405 \\
\hline Corn ear (ton/ha) & 1.8 & 2.2 & 1.7 & 2.3 & 2.4 & 0.421 & 0.832 \\
\hline Soybean (kg/ha) & 383 & 904 & 680 & 808 & 963 & 121.0 & 0.146 \\
\hline Total (ton/ha) & 7.3 & 9.2 & 7.9 & 9.2 & 9.5 & 0.758 & 0.475 \\
\hline Soybean proportion (\%) & 4.9 & 9.5 & 9.2 & 8.9 & 10.1 & 1.3 & 0.274 \\
\hline Relative DM yield (\%) & 100 & 126 & 108 & 126 & 130 & - & - \\
\hline
\end{tabular}

a,b Variables having different superscripts in the same rows are significantly different $(p<0.05)$.

SEM, standard error of the mean.

Table 5. Effect of different herbicide on NDF, ADF, RFV, TDN percentage in corn soybean intercropping forage

\begin{tabular}{|c|c|c|c|c|c|c|c|c|}
\hline \multirow[b]{2}{*}{ Treatments } & \multicolumn{2}{|c|}{ NDF } & \multicolumn{2}{|c|}{ ADF } & \multicolumn{2}{|c|}{ RFV } & \multicolumn{2}{|c|}{ TDN } \\
\hline & $\begin{array}{c}\text { Corn } \\
(\%)\end{array}$ & $\begin{array}{c}\text { Soybean } \\
(\%)\end{array}$ & $\begin{array}{c}\text { Corn } \\
(\%)\end{array}$ & $\begin{array}{c}\text { Soybean } \\
(\%)\end{array}$ & $\begin{array}{c}\text { Corn } \\
(\%)\end{array}$ & $\begin{array}{c}\text { Soybean } \\
(\%)\end{array}$ & $\begin{array}{c}\text { Corn } \\
(\%)\end{array}$ & $\begin{array}{c}\text { Soybean } \\
(\%)\end{array}$ \\
\hline Non-herbicide & 74.1 & 58.0 & 45.7 & 44.5 & 111.6 & 142.7 & 56.1 & 56.9 \\
\hline Pendimethalin & 65.4 & 57.8 & 39.3 & 45.1 & 126.6 & 143.3 & 60.5 & 56.5 \\
\hline Linuron & 67.5 & 57.7 & 40.2 & 44.5 & 123.1 & 143.2 & 59.9 & 56.9 \\
\hline S-metolachlor & 69.3 & 60.1 & 42.7 & 46.5 & 119.6 & 137.6 & 58.1 & 55.5 \\
\hline Ethalfulralin & 67.8 & 59.7 & 41.7 & 47.0 & 122.3 & 138.5 & 58.8 & 55.2 \\
\hline SEM & 1.7 & 0.9 & 1.2 & 0.9 & 3.0 & 2.2 & 0.8 & 0.6 \\
\hline$p$-values & 0.15 & 0.43 & 0.11 & 0.49 & 0.16 & 0.46 & 0.11 & 0.49 \\
\hline
\end{tabular}

NDF, neutral detergent fiber; ADF, acid detergent fiber; RFV, relative feed value; TDN, total digestible nutrients; SEM, standard error of the mean.

Linuron herbicide but its difference with all treatment was not significant $(p>0.05)$. The emergence of last weed named, "Echinochloa crus-galli" was found zero in $S$-metolachlor herbicide. Its emergence was found higher $(p<0.05)$ in control treatment than all other treatments. However, weed emergence was significantly reduced in all herbicidal treatments as compared to that of control but the difference among herbicidal treatments was non-significant.

\section{Discussion}

Findings regarding influence of different herbicides over corn-soybean coupling depicted that the effect of tested herbicides in this study was comparable in terms of improved corn-soybean coupling which was higher to control treatment. The possible factor might be effective control of weeds through herbicides as documented by previous studies [14-16]. The findings of this study regarding impact of Pendimethalin on coupling was also in line to previous study by Kim et al. [14]. The possible reason might be attributed to factor of effectiveness against weeds through its inhibitory action on cell division of broader leaves and finally improved corn-soybean coupling [17]. Pandey and Prakash [18] also substantiated improvement in yield of corn-soybean intercropping through Pendimethalin treatment. However, arithmetic increase in other growth characteristics of corn-soybean forage over control treatment was found but in fact not influenced statistically. The possible reason might be little variation in data generated in this study. In case of 
Table 6. Effect of different herbicides on following weed emergence in corn-soybean mixed cropping fields

\begin{tabular}{|c|c|c|c|c|c|c|c|}
\hline \multirow{2}{*}{ Weed emergence parameters } & \multicolumn{5}{|c|}{ Treatments } & \multirow{2}{*}{ SEM } & \multirow{2}{*}{$p$-value } \\
\hline & No herbicide & Pendimethalin & Linuron & S-metolachlor & Ethalfluralin & & \\
\hline Chenopodium album $\left(\mathrm{No} / \mathrm{m}^{2}\right)$ & 159.3 & 0 & 0 & 105.6 & 27.8 & 30.8 & 0.062 \\
\hline Digitaria sanguinalis $\left(\mathrm{No} / \mathrm{m}^{2}\right)$ & $509.3^{b}$ & $31.5^{\mathrm{a}}$ & $266.7^{\mathrm{ab}}$ & $16.7^{\mathrm{a}}$ & $9.3^{\mathrm{a}}$ & 60.8 & 0.004 \\
\hline Portulaca oleracea $\left(\mathrm{No} / \mathrm{m}^{2}\right)$ & 35.2 & 20.4 & 0 & 22.2 & 25.9 & 7.5 & 0.208 \\
\hline Echinochloa crus-galli $\left(\mathrm{No} / \mathrm{m}^{2}\right)$ & $335.2^{b}$ & $64.8^{\mathrm{a}}$ & $1.9^{\mathrm{a}}$ & $0^{a}$ & $61.1^{\mathrm{a}}$ & 16.7 & $<.0001$ \\
\hline
\end{tabular}

${ }^{a, b}$ Variables having different superscripts in the same rows are significantly different $(p<0.05)$.

SEM, standard error of the mean.

optimum total DM yield, although effect of tested herbicides was also comparable. Possible reason for highest DM yield in Ethalfluralin treatment followed by Pendimethalin and $S$-metolachlor might be the same pattern of corn-soybean coupling number in this study. The weed emergence of Pendimethalin and Ethalfuralin were higher levels on whole groups and the total number of weeds were 116.7 and $124.1 \mathrm{no} / \mathrm{m}^{2}$, respectively. The effective control of Linuron against weed emergence might be due to the factor of its inhibition of photosystem-II which was important for photosynthetic electron transport in plants [17]. However, relative DM yield in current study was found lowest in case of Linuron herbicide. The possible reason might be its less suitability factor for corn-soybean mixed forage. The highest relative DM yield in case Ethalfluralin treatment might be due its effective control over weed emergence. Ethalfuralin is dinitroaniline herbicides in nature with inhibition of cell mitosis [19], whereas effect of Pendimethalin over DM yield was also documented previously by Kim et al. [14]. Similarly, the $S$-metolacblor was already substantiated and environmentally friendly herbicide used for sustainable weed management which enhanced the relative DM yield 126\% in current study [20].

Keeping in view the above discussion, it was concluded that weed emergence can be effectively controlled by use of any tested herbicide. However, optimum DM yield can be achieved through using herbicides; Ethafluralin, Pendimethalin and $S$-metolachlor. However, in present study results variation indicated that whole herbicides are not able to recommend yet. The finding high stability herbicide is generally important on sustainable agriculture.

\section{Competing interests}

No potential conflict of interest relevant to this article was reported.

\section{Funding sources}

Not applicable.

\section{Acknowledgements}

This work was supported by Korea Institute of Planning and Evaluation for Technology in Food, Agriculture, Forestry and Fisheries (IPET) through Agri-Bio industry Technology Development
Project, funded by Ministry of Agriculture, Food and Rural Affairs (MAFRA) (314024-3).

\section{Availability of data and material}

Upon reasonable request, the datasets of this study can be available from the corresponding author.

\section{Authors' contributions}

Conceptualization: Kwon $\mathrm{CH}$.

Data curation: Fiaz M.

Formal analysis: Song Y, Fiaz M.

Methodology: Kwon CH, Fiaz M.

Software: Song Y, Fiaz M.

Validation: Kwon CH.

Investigation: Kim DW, Kim J.

Writing - original draft: Song Y.

Writing - review \& editing: Kwon $\mathrm{CH}$.

\section{Ethics approval and consent to participate}

This article does not require IRB/LACUC approval because there are no human and animal participants.

\section{ORCID}

Yo wook Song https://orcid.org/0000-0002-1311-9399 Chan Ho Kwon https://orcid.org/0000-0003-4602-0093

Muhammad Fiaz https://orcid.org/0000-0002-3398-5243 Jeongtae Kim https://orcid.org/0000-0001-8080-9114 Dong Woo Kim https://orcid.org/0000-0003-3697-909X

\section{References}

1. KOSTAT. 2018. Livestock statistics in the third quarter of 2018. http://kostat.go.kr/portal/eng/pressReleases/1/index. board?bmode=read\&aSeq=371512. Accessed at 30 Jan 2019.

2. Seo JD, Choe JH, Park JH, Kim MS, Kwon CH, Lee JD. Yield and quality of forage produced by mixed planting of soybean and corn. Curr Res Agric Life Sci. 2014;32:105-9.

3. Zimdahl RL. Fundamentals of weed science. Waltham, 
MA: Academic Press; 2013. p.295-344.

4. Thobasti JT. Growth and yield responses of maize (Zea mays L.) and cowpea (Vigna unguiculata L.) in an intercropping system [Ph.D. dissertation]. South Africa: University of Pretoria; 2009. p.159.

5. Griepentrog HW, Dedousis AP. Mechanical weed control. In: Dedousis AP, Bartzanas T, editors. Soil engineering. Berlin, Germany: Springer; 2010. p.171-9.

6. Bergin D. Weed control options for coastal sand dunes: a review. New Zealand: New Zealand Forest Research Institute; 2011.25 p.

7. Rueda-Ayala VP, Rasmussen J, Gerhards R, Fournaise NE. The influence of post-emergence weed harrowing on selectivity, crop recovery and crop yield in different growth stages of winter wheat. Weed Res. 2011;51:478-88.

8. Chauvel B, Guillemin JP, Gasquez J, Gauvrit C. History of chemical weeding from 1944 to 2011 in France: changes and evolution of herbicide molecules. Crop Prot. 2012;42:320-6.

9. Judith CS, Lemley AT, Hogan SI, Weismiller RA, Hornsby AG. Health effects of drinking water contaminants. Gainesville, FL: University of Florida; 2001. p.1-9.

10. Korea Meteorological Administration. 2016. Meteorological observation. https://data.kma.go.kr/data/grnd/selectAsosRltmList.do?pgmNo=36. Accessed at 30 Jan 2019.

11. Van-Soest PJ, Robertson JB, Lewis BA. Methods for dietary fiber, neutral detergent fiber, and nonstarch polysaccharides in relation to animal nutrition.J Dairy Sci. 1991;74:3583-97.
12. NFTA. 2016. Forage analysis procedures. National Forage Testing Association. https://www.foragetesting.org/. Accessed at 30 Jan 2019.

13. Steel RGR, Torrie JH, Dickey DA. 1997. Principles and procedures of statistics: a biometrical approach. 3rd ed. New York, NY: McGraw Hill; 1997. p.672.

14. Kim DW, Song Y, Kim J, Fiaz M, Kwon CH. Effect of different herbicides on forage yield and nutritive value in corn-soybean mixture cropping. J Korean Soc Grassl Forage Sci. 2017;37:108-15.

15. McWhorter CG, Anderson JM. Bentazon applied postemergence for economical control of common cocklebur in soybeans. Weed Sci. 1976;24:391-6.

16. Oliver LR. Influence of soybean (Glycine max) planting date on velvetleaf (Abutilon theophrasti) competition. Weed Sci. 1979;27:183-8.

17. Roberts TR. Metabolic pathways of agrochemicals: part 1 : herbicides and plant growth regulators. Cambridge, UK: Royal Society of Chemistry; 1998. p.270.

18. Pandey AK, Prakash V. Weed management in maize and soybean intercropping system. Indian J Weed Sci. 2002;34:58-62.

19. Appleby AP, Valverde BE. Behavior of dinitroaniline herbicides in plants. Weed Sci Soc Am. 1989;3:198-206.

20. O'Connell PJ, Harms CT, Allen JRF. Metolachlor, S-metolachlor and their role within sustainable weed-management. Crop Prot. 1998;17:207-12. 